\title{
The Exploration and Practice of Multi-dimension Training Mode of Information Innovative Talents
}

\author{
Henghua Shi ${ }^{1, a}$ and Xin $X u^{2, b, *}$ \\ ${ }^{1}$ School of Computer and Information Engineering, Beijing University of Agriculture, China \\ ${ }^{2}$ Communication Technology Bureau, Xinhua News Agency, China \\ ahenghuashi@163.com, byouges@163.com \\ ${ }^{*}$ Corresponding author
}

Keywords: Exploration; Practice; Multi-dimension; Training Mode; Innovative Talents

\begin{abstract}
The innovative talents have become a hot point demand of information talents in the current society. The training mode of " $3+1 "$ information innovative talents will become the direction of information talents training. Based on the " $3+1 "$ talents training in the current domestic universities, we develop the exploration and practice of the multi-dimension talents training in five dimensions and analyze the core content of each dimension for the corresponding implementation mechanism.
\end{abstract}

\section{Introduction}

There is a great demand for information talents in society. The information talents training occupy an important place in economic construction and social life. However, there are still many problems in the current training mode of information talents, such as lack of innovation, serious unemployment and employment pressure. In order to meet the changing needs of the information talents in the society, domestic universities have developed the " $3+1 "$ mode of training information talents in recent years [1-2]. This changing can absolve the problem that the existing training mode of talents in universities cannot meet the requirements of enterprises [3-9]. At the same time, it puts forward the types of information talents training, that is, so-called information innovative talents. The so-called "innovative talents" is full of originality, creativity, to propose and solve problems, create a new situation, make a creative contribution to the social material and spiritual civilization of human [10]. Therefore, the research on the training mode of " $3+1$ " information innovative talents has become the focus of the talents training at a future stage.

The multi-dimension of the training mode of talents refers to many dimensions in the process of the talents training. In this paper, based on the " $3+1 "$ talents training in the current domestic universities, we develop the exploration and practice of the multi-dimension talents training and divide the multi-dimension into five dimensions such as professional training program, practice teaching system, innovation ability promotion, teaching method reform, professional tutor team. Then, we analyze the core content of each dimension for the corresponding implementation mechanism.

\section{The Analysis of Multi-dimension Training Mode}

There are five dimensions of the training mode of " $3+1$ " information innovative talents, and each dimension has a lot of the contents. We select ability training, professional practices, academic competitions, turn over classes and professional tutors as the core content with each dimension. Then, we analyze the core content of each dimension for the corresponding implementation mechanism of five dimensions such as professional training program, practice teaching system, innovation ability promotion, teaching method reform, professional tutor team. The core content multi-dimension of the training mode of " $3+1$ " information innovative talents are as the following: 


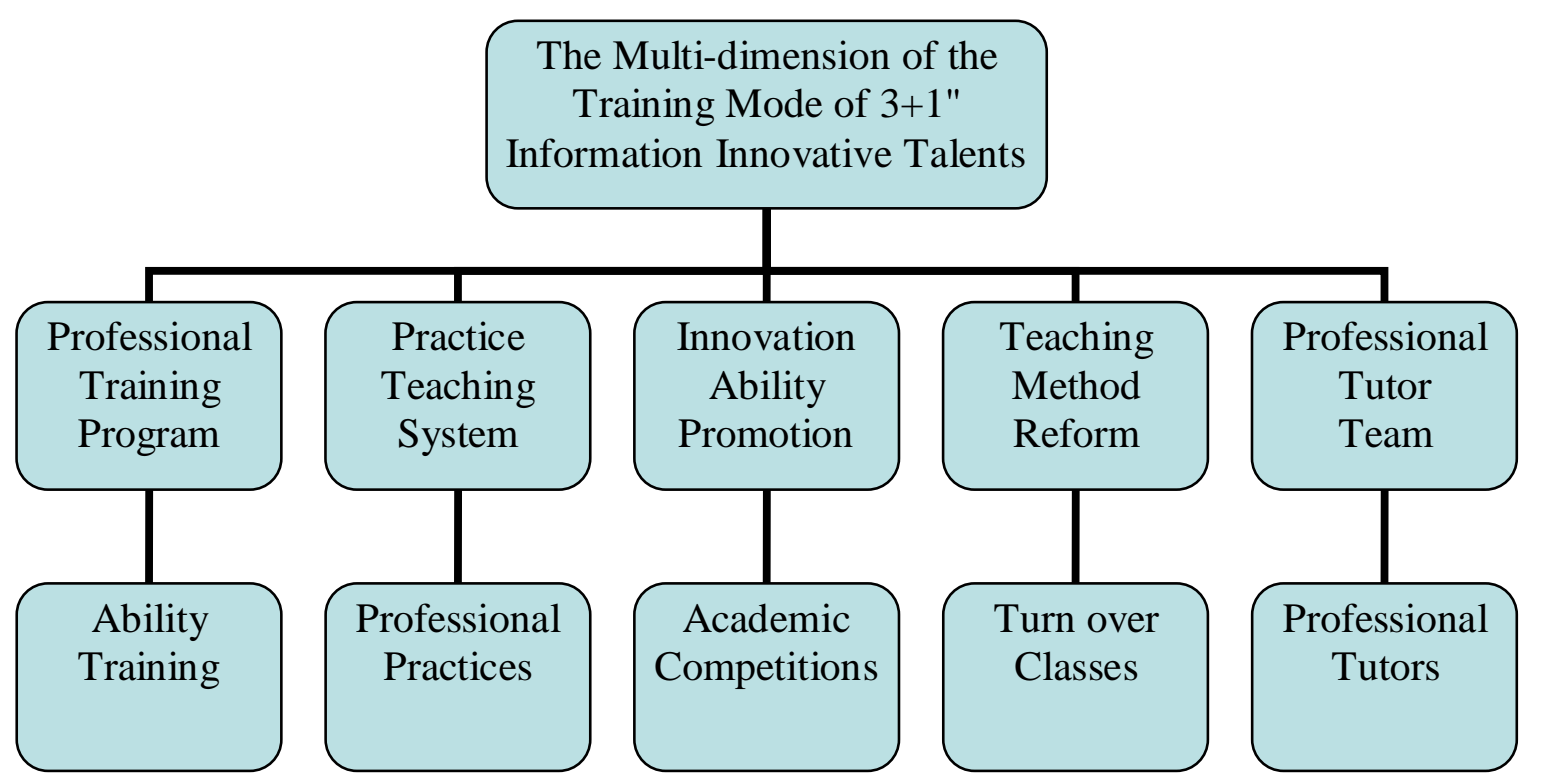

Fig. 1 The core content multi-dimension of the training mode of " $3+1$ " information innovative

talents

In Fig.1, we can see there is a certain relationship between the 5 dimensions of the multi-dimension of the training mode of " $3+1 "$ information innovative talents. For example, the development of the professional training program, the direction will be clear ability training, so as to promote the reform of the teaching method. In the same time, classroom teaching by means of turning the reform of teaching method will enhance the students' autonomous learning ability, thus effect of practice teaching system.

We can also see that professional practice pay attention to business practice teaching system will enhance the students' awareness of innovation, thus completing the innovation ability. Then, innovation ability will promote students to participate in academic competitions. Students to participate in academic competitions and other activities, but also to promote teachers' professional development to enhance individual ability, ultimately, enhance the tutor team. At last, the development of professional instructors and professional instructors personal ability, conducive to the development of the professional training program. The benign interaction and synergy between these five dimensions can effectively promote and strengthen the training mode of " $3+1$ " information innovative talents.

\section{The Analysis of Five Dimensions and the Core Content}

Professional Training Program Dimension for Ability Training. The revision of the professional training plan need through several times of social demand investigation and the relevant experts fully demonstrated. From the perspective of social enterprise to examine the curriculum content and restructure of the existing curriculum system. Then, we can construct the training mode of " $3+1$ " information innovative talents. In the curriculum system setting, we should highlight the "ability training", and see "ability training" as the core to strengthen the basic knowledge, widening the range of professional knowledge, development ability and thinking ability of system engineering.

Practice Teaching System Dimension to Professional Practices. In the reform of teaching methods, the use of flipped classroom teaching method can improve students' autonomous learning ability, and will affect the development of practical teaching system. At the basic stage of discipline, students should carry out basic verification and comprehensive design experiments to strengthen basic professional skills. The learning phase in the professional direction, students can choose the professional direction according to their own characteristics and interests, to carry out the tasks according to the direction of the driving practical and innovative professional research, cultivate and enhance their professional skills and practical innovation ability. The most important thing is to carry out professional practice in the enterprise, and carry out practical training of engineering 
projects according to the actual project in the enterprise professional practice stage, so as to train students' engineering quality and engineering practice ability.

Innovation Ability Promotion Dimension as Academic Competitions. The practice teaching system will strengthen the students' innovative consciousness, so as to achieve the promotion of innovative ability. Reflect the innovation capability can be demonstrated through various information science competitions, such as undergraduate electronic design, networking applications, program design, mathematical modeling, subject contest, the construction of classroom teaching, extracurricular counseling, academic competitions and professional ability training system relative access, to further strengthen the students' professional skills. By participating in the technical research of the subject competition, students are trained to solve their practical problems with professional knowledge, and students' engineering practice ability and innovative consciousness are raised.

Teaching Method Reform Dimension as Turn over Classes. After the revision of the professional training program and the direction of ability training, we need to carry out the reform of the corresponding teaching methods. We should make full use of the "flipped classroom" teaching concept and take task driven as the main means to carry out disruptive reforms to the existing classroom teaching model [11-12]. Thoroughly change the existing "Teacher centered" teaching model, and realize the "student centered" teaching in the true sense. The core of knowledge transfer and knowledge internalization will be turned over, and the original closed training mode will be broken.

Professional Tutor Team Dimension for Professional Tutors. Students' participation in subjects, competitions and other activities can also promote teachers to enhance their personal abilities and develop professional tutors. You can establish a multi-level system of professional instructors, in school, students can be in the form of group by departments assigned professional instructors, students participate in professional training, for student academic guidance and non academic help. For professional practice to achieve "double tutor system" in the enterprise, which is the school teacher by professional instructors who, by the cooperation of extramural enterprises selected as the backbone technology, a comprehensive assessment of the cultivation of the students' learning stage in the enterprise. Through the establishment of multi-level professional tutor system, it is possible to develop professional tutor team and professional instructors to enhance their personal ability, which is conducive to the formulation of professional training programs.

\section{Summary}

There is a great demand for information talents in society. The innovative talents have become a hot point demand of information talents in the current society. In this paper, we develop the exploration and practice of the multi-dimension talents training based on the " $3+1$ " talents training in the current domestic universities.

We divide the multi-dimension talents training into five dimensions including professional training program, practice teaching system, innovation ability promotion, teaching method reform, professional tutor team. Then, we select ability training, professional practices, academic competitions, turn over classes and professional tutors as the core content with each dimension. According to the analysis of the core content of each dimension, we can see the corresponding implementation mechanism with the multi-dimension talents training..

\section{Acknowledgement}

Corresponding author is $\mathrm{Xu}$ Xin. The authors would like to acknowledge the supports provided by 2017 Education and Teaching Reform Program of Beijing University of Agriculture "The Exploration and Practice of the Training Mode of ' $3+1$ ' Information Innovative Talents" 


\section{Reference}

[1] Wang Huimin, et al. Innovating the Training Mode of " $3+1$ " to Strengthen the Practical Ability of Urban Agricultural Talents. Higher Agricultural Education, 2012 (10): 3-5

[2] Song Zuozhong, et al. Research on Personnel Training Mode of " $3+1$ " in School Enterprise Cooperation. Heilongjiang Higher Education Research, 2013, 31 (5): 154-157

[3] Li Rong, et al. Exploration of Training Mode of Applied Innovative Talents in Independent College. Higher Engineering Education Research, 2005 (1): 73-75

[4] Wang Jinting, et al. Training of Innovative Talents of Electronic Information in Application-oriented Universities. Journal of Hubei University of Economics (Humanities and Social Sciences), 2013 (7): 186-187

[5] Lin Leping, et al. Give Full Play to the Advantages of Discipline and Construct a Training System for Innovative Talents of Electronic Information Engineering. China Electric Power Education, 2012 (12): 22-23

[6] Wu Lili, et al. Research on the Training Mode of Innovative and Applied Talents for Electronic Information Specialty. China Electric Power Education, 2011 (11) :94-95

[7] Geng Haiyun. Research on the Training Mode of Electronic Information Innovative Talents. New Observation, 2012 (21) :14-14

[8] Zhang Xiaodong, et al. Exploration of Training Mode for Innovative Talents Majoring in Electrical Information in Agricultural Colleges. Chinese Agricultural Science Bulletin, 2011 , 27 (23) :193-198

[9] Zhu Hong. Exploration and Practice of Innovative Talents Training Mode in Higher Education Institutions. University Education Administration, 2008 (3): 6-11

[10] Xu Songpu, et al. Exploration and Practice of Personnel Training Mode of Information Talents "3.5+0.5" . China Education Innovation Herald. 2008 (35) 15.

[11] ChenSong, Pan Li, Li Wen, et al. Exploration an Practice of Project Driven Mode for Innovation Base. Journal of EEE, 2010, 32(5):105-106.

[12] Pan Li, Zhang Guoyun, Li Wu, et al. MOOC Oriented Three Stage Flipped Classroom Teaching Model. China Education Information, 2015, (2): 16-18 